Article

\title{
One-Pot Synthesis and Characterization of $\mathrm{VO}_{2}(\mathrm{~B})$ with a Large Voltage Window Electrochemical Performance in Aqueous Solution
}

\author{
Xiaoyu Liu, Jiqi Zheng, Xuyang Jing, Yan Cheng and Changgong Meng * \\ School of Chemical Engineering, Dalian University of Technology, Dalian 116024, China; \\ xyliu2003@dlut.edu.cn (X.L.); len@mail.dlut.edu.cn (J.Z.); jingxy@mail.dlut.edu.cn (X.J.); \\ 291237629@mail.dlut.edu.cn (Y.C.) \\ * Correspondence: cgmeng@dlut.edu.cn
}

Received: 3 April 2020; Accepted: 14 April 2020; Published: 16 April 2020

\begin{abstract}
B-type vanadium dioxide (defined as $\mathrm{VO}_{2}(\mathrm{~B})$ ) nanobelts were synthesized through using commercial ammonium metavanadate, oxalic acid via one-step hydrothermal technique. The structure of $\mathrm{VO}_{2}(\mathrm{~B})$ was characterized using different instruments. $\mathrm{N}_{2}$ adsorption-desorption isotherms revealed that the $\mathrm{VO}_{2}(\mathrm{~B})$ nanobelts were porous structures where BET surface area was $10.4 \mathrm{~m}^{2} \cdot \mathrm{g}^{-1}$, the pore volume was $0.0687 \mathrm{~cm}^{3} / \mathrm{g}$, and the average pore size was $42.7 \mathrm{~nm}$. Furthermore, the $\mathrm{VO}_{2}(\mathrm{~B})$ nanobelts as supercapacitors electrode exhibited a large voltage window $(-0.8 \sim 1.0 \mathrm{~V})$. The measured capacitance was based on the pseudocapacitance. When the discharge current density is $0.5,1$, and $10 \mathrm{~A} \cdot \mathrm{g}^{-1}$, the $\mathrm{VO}_{2}(\mathrm{~B})$ shows the specific capacitance of 287,246 , and $222 \mathrm{~F} \cdot \mathrm{g}^{-1}$, respectively.
\end{abstract}

Keywords: $\mathrm{VO}_{2}$; nanobelts; hydrothermal synthesis; pseudocapacitance

\section{Introduction}

Recently, the strategy for systematically designing the morphology and structure of diverse inorganic materials has been a cutting-edge research focus owing to the novel physical and chemical properties essentially affected by their shapes and sizes [1-5]. Particularly, nanobelts have been paid great attention due to their novel physical and chemical properties and wide application prospects [6,7]. Moreover, supercapacitors (SCs) are considered as one of the most attractive pieces of new-generation apparatus in energy storage, and their performance is closely related to the characteristics of electrode materials. Metal oxides with novel structures show excellent specific capacitance and energy density because of their energy storage mechanism [8-10]. Meanwhile, there is a wide utilization in various fields, such as energy, biology, gas sensors, etc. [11-13].

After the discovery of $\mathrm{VO}_{2}$, it aroused great interest among scientists for its structural phase transition [14,15], and the crystallography data of $\mathrm{VO}_{2}$ polymorphs were studied systemically (in Table 1) [16-21]. In the past decades, B-type vanadium dioxide (defined as $\mathrm{VO}_{2}(\mathrm{~B})$ ) has attracted widespread attention to the application of lithium-ion batteries due to its chemical structural characteristics [22,23]. Nowadays, $\mathrm{VO}_{2}(\mathrm{~B})$ has arisen people's interest in the field of supercapacitors. For examples, concerning one kind of $\mathrm{VO}_{2}(\mathrm{~B})$ nanobelts, it was reported that a specific capacitance of $142 \mathrm{~F} \cdot \mathrm{g}^{-1}$ is displayed at the voltage window limit of $-0.4 \sim 0.6 \mathrm{~V}$ [24]. Concerning $\mathrm{VO}_{2}(\mathrm{~B})$ nanosheets, [25] reported that the particles show a high rate capability of $200 \mathrm{mAh} \mathrm{g}^{-1}$. Furthermore, hybrid materials related to $\mathrm{VO}_{2}(\mathrm{~B})$ were also developed to apply to the material of the electrodes. For instance, $\mathrm{VO}_{2}(\mathrm{~B}) / \mathrm{C}$ were synthesized through the hydrothermal method, which exhibited the specific capacitance of $182 \mathrm{~F}^{-1} \mathrm{~g}^{-1}$ when the voltage window limit is $-0.6 \sim 0.8 \mathrm{~V}$. The $\mathrm{VO}_{2}(\mathrm{~B}) / \mathrm{rGO}$ composites exhibited a capacity of $456 \mathrm{mAh} \mathrm{g}^{-1}$ [26]. According to the published data, the electrochemical 
properties of $\mathrm{VO}_{2}(\mathrm{~B})$ as SCs remains to be optimized further. Therefore, it is necessary and significant for material researchers to improve the specific capacitance or voltage window.

Table 1. The crystal data of $\mathrm{VO}_{2}$ polymorphs.

\begin{tabular}{cccccc}
\hline Phase & Transition Temperature (K) & $\mathbf{a}(\AA)$ & $\mathbf{b}(\AA)$ & $\mathbf{c}(\AA)$ & Crystal System \\
\hline $\mathrm{VO}_{2}(\mathrm{M})$ & 341 & 5.74 & 4.16 & 5.38 & Monoclinic \\
$\mathrm{VO}_{2}(\mathrm{R})$ & 341 & 4.53 & 4.53 & 2.87 & Monoclinic \\
$\mathrm{VO}_{2}(\mathrm{~A})$ & 435 & 8.44 & 8.44 & 7.67 & Tetragonal \\
$\mathrm{VO}_{2}(\mathrm{~B})$ & - & 12.03 & 3.69 & 6.42 & Tetragonal \\
\hline
\end{tabular}

In this paper, we designed a simple and convenient route to synthesize $\mathrm{VO}_{2}(\mathrm{~B})$ nanobelts. That is, $\mathrm{NH}_{4} \mathrm{VO}_{3}$ is reduced by $\mathrm{H}_{2} \mathrm{C}_{2} \mathrm{O}_{4} \cdot 2 \mathrm{H}_{2} \mathrm{O}$ using hydrothermal method without adding any template or surfactant. cyclic voltammetry $(\mathrm{CV})$ and galvanostatic charge-discharge (GCD) tests have been applied to assess the electrochemical properties of the $\mathrm{VO}_{2}(\mathrm{~B})$ nanobelts.

\section{Experiment and Characterization}

The chemicals (analytical grade) in the experiment need not be purified any more. The synthesis of $\mathrm{VO}_{2}(\mathrm{~B})$ nanobelts is divided into the following steps. Firstly, $0.585 \mathrm{~g}$ of $\mathrm{NH}_{4} \mathrm{VO}_{3}, 1.103 \mathrm{~g}$ of $\mathrm{H}_{2} \mathrm{C}_{2} \mathrm{O}_{4} \cdot 2 \mathrm{H}_{2} \mathrm{O}\left(\mathrm{NH}_{4} \mathrm{VO}_{3}: \mathrm{H}_{2} \mathrm{C}_{2} \mathrm{O}_{4} \cdot 2 \mathrm{H}_{2} \mathrm{O}=1: 1.75\right.$, abbreviate $\left.\mathrm{V}: \mathrm{C}=1: 1.75\right)$ were blended together with $35 \mathrm{~mL}$ distilled water. After stirring for $30 \mathrm{~min}$, the mixture was kept at $180{ }^{\circ} \mathrm{C}$ for $48 \mathrm{~h}$ in a $50-\mathrm{mL}$ Teflon-lined stainless steel autoclave. Subsequently, the products were washed and dried at $75^{\circ} \mathrm{C}$ for $12-24 \mathrm{~h}$.

X-ray powder diffraction (XRD) was tested in Panalytical X'Pert powder MPD with Cu K $\alpha$ radiation. Fourier transform infrared spectroscopy (FT-IR) was applied to measure the products with Nicolet 6700. The Raman spectra were carried out with a 532-nm excitation line (Thermo Scientific, MA, USA). Morphology and dimensions were measured through scanning electron microscopy (SEM) on QUANTA450, and transmission electron microscopy (TEM) on FEITECNAIG220. The surface area was determined on ASAP-2020 through the Brunauer-Emmet-Teller (BET) method.

A three-electrode cell was employed in the electrochemical test. The working electrode was prepared via the following steps. Firstly, mix $10 \mathrm{wt} \%$ of carbon black, $10 \mathrm{wt} \%$ of polyvinylidene difluoride, and $80 \mathrm{wt} \%$ of $\mathrm{VO}_{2}$ (B) together, and then put $\mathrm{N}$-methyl-2-pyrrolidone into the mixture. Next, the slurries were coated on a nickel foil. After heating at $80^{\circ} \mathrm{C}$ for $24 \mathrm{~h}$, these nickel foils were pressed on a Ni grid under the pressure of $10 \mathrm{MPa}$. An amount of $1.0 \mathrm{~mol} \cdot \mathrm{L}^{-1} \mathrm{Na}_{2} \mathrm{SO}_{4}$ aqueous solution was chosen as the electrolyte. The electrochemical characteristics using $\mathrm{CV}$ and GCD were performed on $\mathrm{CHI}$ 660D. The specific capacitance $\left(\mathrm{C}, \mathrm{F} \cdot \mathrm{g}^{-1}\right)$, energy density $\left(\mathrm{E}, \mathrm{W} \cdot \mathrm{h} \cdot \mathrm{kg}^{-1}\right)$ and the power density $\left(\mathrm{P}, \mathrm{W} \cdot \mathrm{kg}^{-1}\right)$ are determined through Equation (1) to Equation (3).

$$
\begin{gathered}
\mathrm{C}=\frac{\mathrm{I} \cdot \Delta \mathrm{t}}{\mathrm{m} \cdot \Delta \mathrm{V}} \\
\mathrm{E}=\frac{1}{7.2} \mathrm{C} \cdot(\Delta \mathrm{V})^{2} \\
\mathrm{P}=\frac{3600 \mathrm{E}}{\Delta \mathrm{t}}
\end{gathered}
$$

where, $\mathrm{I}(\mathrm{A})$ denotes the discharge current. $\Delta \mathrm{t}(\mathrm{s})$ denotes the discharge time. $\mathrm{m}(\mathrm{g})$ denotes the mass of the $\mathrm{VO}_{2}(\mathrm{~B}) . \Delta \mathrm{V}(\mathrm{V})$ denotes the potential drop during the process of discharge.

\section{Results and Discussion}

The synthetic conditions took a significant part in the formation of $\mathrm{VO}_{2}(\mathrm{~B})$ nanobelts. Figure $1 \mathrm{~A}$ demonstrates the XRD pattern of the samples at various ratio of $\mathrm{V}: \mathrm{C}$. When the ratio of $\mathrm{V}: \mathrm{C}$ is $1: 1.25$, 
an unknown solid was obtained based on our knowledge. With the increase of $\mathrm{V}: \mathrm{C}$, the characteristic peaks of $\mathrm{VO}_{2}$ (B) (JCPDS, No. 81-2392) were obtained and pure phase of $\mathrm{VO}_{2}(\mathrm{~B})$ was synthesized with $\mathrm{V}: \mathrm{C}$ and increased to 1:1.75. However, when $\mathrm{V}: \mathrm{C}$ continued to increase $(\mathrm{V}: \mathrm{C}=1: 2), \mathrm{VO}_{2}(\mathrm{~B})$ was not obtained and other vanadium oxides were prepared. Thus, $\mathrm{V}: \mathrm{C}=1: 1.75$ is suitable for the synthesis of $\mathrm{VO}_{2}(\mathrm{~B})$ with pure phase. Figure $1 \mathrm{~B}$ describes the $\mathrm{XRD}$ patterns of $\mathrm{VO}_{2}(\mathrm{~B})$ prepared with various hydrothermal times, which discloses the evolution process of $\mathrm{VO}_{2}(\mathrm{~B})$ 's formation. As depicted in Figure $1 \mathrm{~B}, \mathrm{VO}_{2}(\mathrm{~B})$ was obtained at $6-96 \mathrm{~h}$ indicating that $\mathrm{VO}_{2}(\mathrm{~B})$ could be synthesized in a short time.
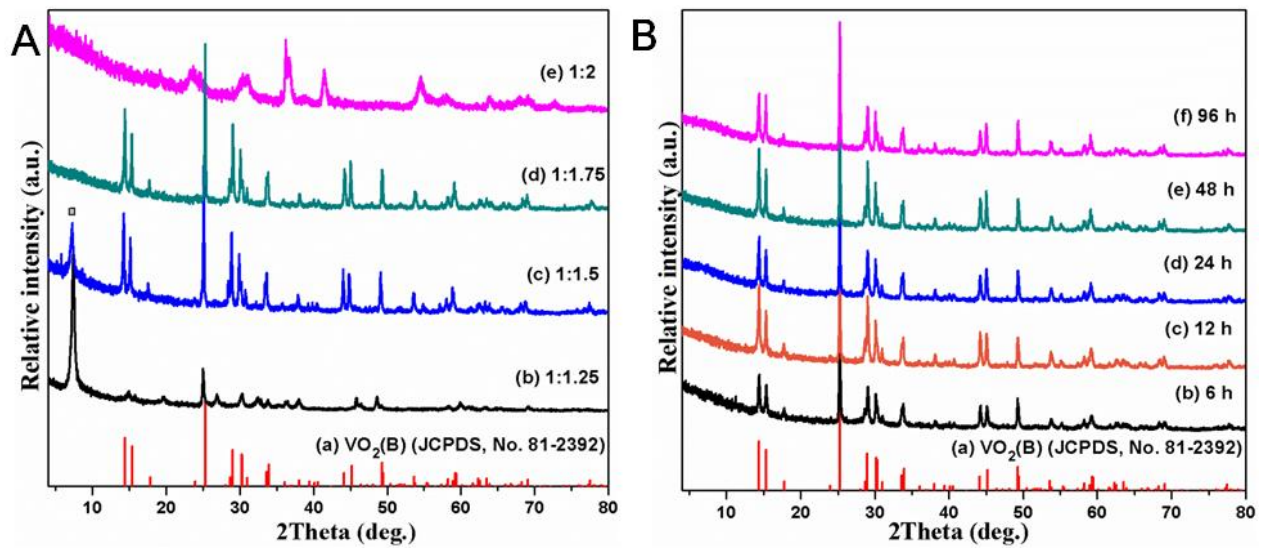

Figure 1. XRD patterns of the samples with various conditions: (A) various ratio of $\mathrm{V}: \mathrm{C}\left(180{ }^{\circ} \mathrm{C}, 48 \mathrm{~h}\right)$; (B) reaction time $\left(\mathrm{V}: \mathrm{C}=1: 1.75,180^{\circ} \mathrm{C}\right)$.

Figure 2 shows the morphology of the samples obtained by SEM. When V:C $=1: 1.25$, it can be seen that nanosheets are obtained (Figure 2a). With $\mathrm{V}: \mathrm{C}$ increasing to 1:1.75, $\mathrm{VO}_{2}(\mathrm{~B})$ nanobelts are synthesized, as shown in Figure $2 \mathrm{~b}$. Thus, $\mathrm{V}: \mathrm{C}=1: 1.75$ is favorable for preparation of $\mathrm{VO}_{2}(\mathrm{~B})$ with belt-like morphology. The SEM images of the samples obtained at 6 and $12 \mathrm{~h}$ are shown in Figure 2c, $\mathrm{d}$ respectively. They both reveal that $\mathrm{VO}_{2}(\mathrm{~B})$ nanobelts are formed. This result indicates that $\mathrm{VO}_{2}(\mathrm{~B})$ nanobelts can be synthesized at a short time. Figure 3 shows the TEM image of the samples. The TEM images are consistent with SEM images, which also reveals that $\mathrm{VO}_{2}(\mathrm{~B})$ with belt-like morphology could be synthesized.

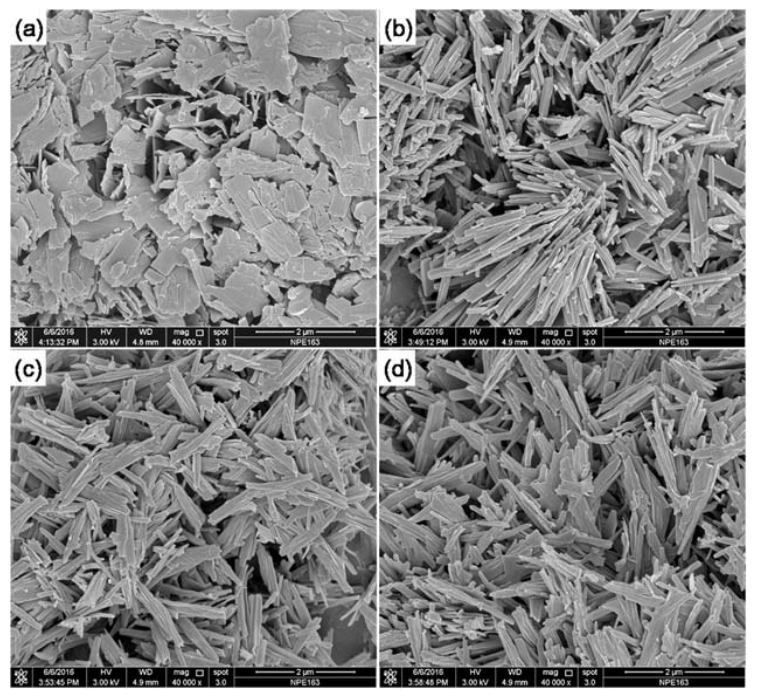

Figure 2. SEM images of the products under various conditions: (a) V:C $=1: 1.25,48 \mathrm{~h} ;(\mathbf{b}) \mathrm{V}: \mathrm{C}=1: 1.75$, $48 \mathrm{~h} ;(\mathbf{c}) \mathrm{V}: \mathrm{C}=1: 1.75,6 \mathrm{~h} ;(\mathbf{d}) \mathrm{V}: \mathrm{C}=1: 1.75,12 \mathrm{~h} .\left(\right.$ at $\left.180^{\circ} \mathrm{C}\right)$. 


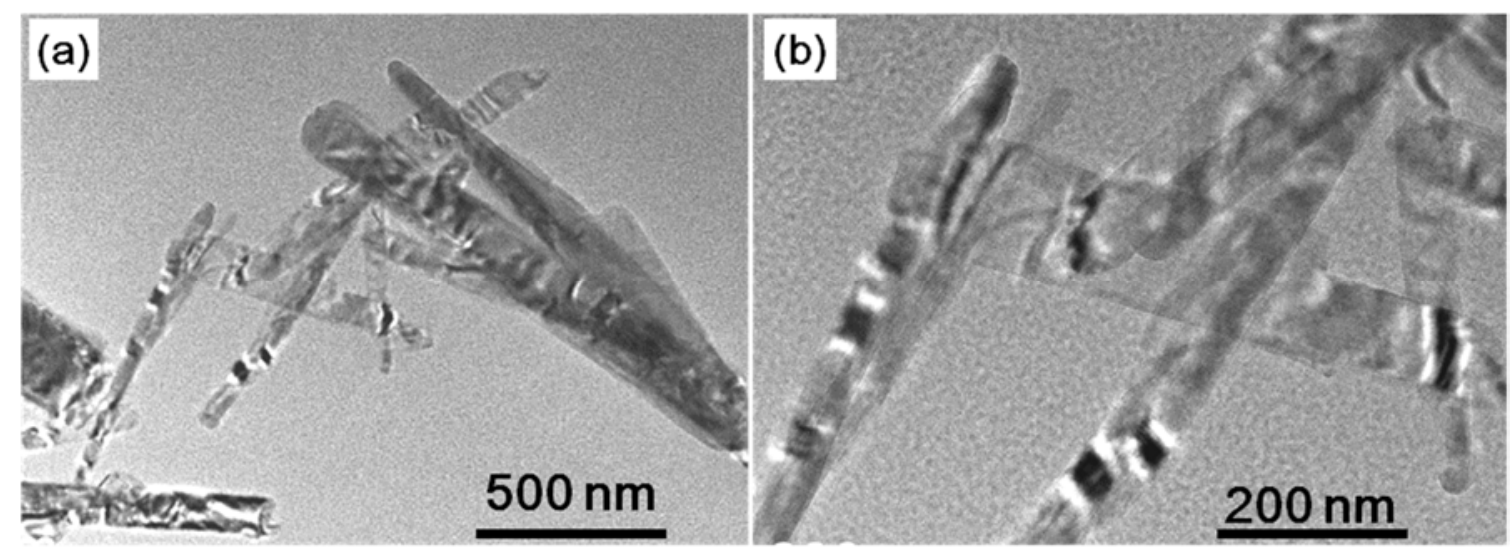

Figure 3. TEM images of the $\mathrm{VO}_{2}$ (B) nanobelts at different scales: (a) $500 \mathrm{~nm}$; (b) $200 \mathrm{~nm}$.

Further composition and structure information about the as-obtained $\mathrm{VO}_{2}(\mathrm{~B})$ was provided by EDS, FTIR, and Raman. The SEM image and its corresponding EDS spectrum of the as-obtained sample is shown in Figure 4, which indicates that the sample composes of vanadium and oxygen elements in consonance with the observation of XRD patterns. The IR and Raman spectra of the as-obtained $\mathrm{VO}_{2}(\mathrm{~B})$ is shown in Figure 5a. The absorption peaks among 1100 and $400 \mathrm{~cm}^{-1}$ are assigned to $\mathrm{V}-\mathrm{O}$ vibration band in the IR spectrum $[27,28]$. The peak at $535 \mathrm{~cm}^{-1}$ is ascribed to the stretching modes of $\mathrm{V}-\mathrm{O}-\mathrm{V}$, and that at $920 \mathrm{~cm}^{-1}$ is ascribed to $\mathrm{V}-\mathrm{O}$ bonds. Meanwhile, the characteristic absorption peak of the $\mathrm{VO}_{2}(\mathrm{~B})$ nanobelts with layered structure is observed at $998 \mathrm{~cm}^{-1}$, which is assigned to the symmetric stretching vibration in $\mathrm{VO}_{2}(\mathrm{~B})\left(\mathrm{V}^{4+}=\mathrm{O}\right)$.
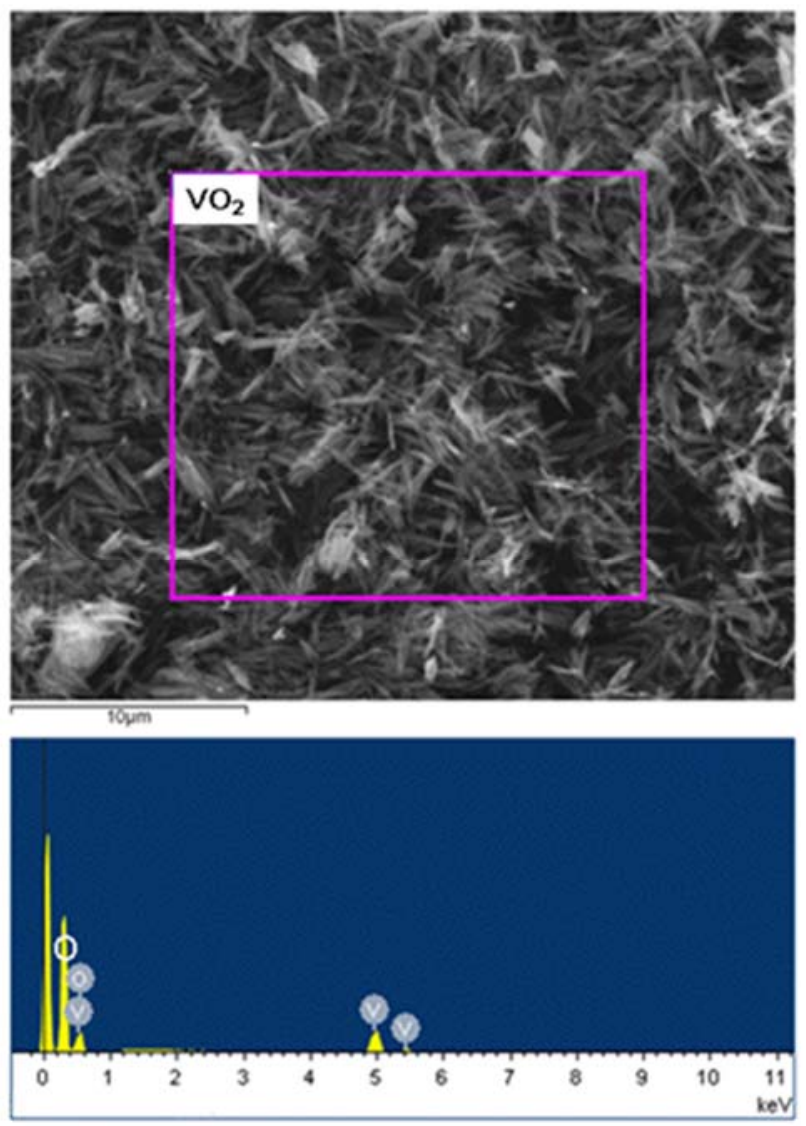

Figure 4. SEM image and EDS spectrum of the $\mathrm{VO}_{2}(\mathrm{~B})$ nanobelts. 

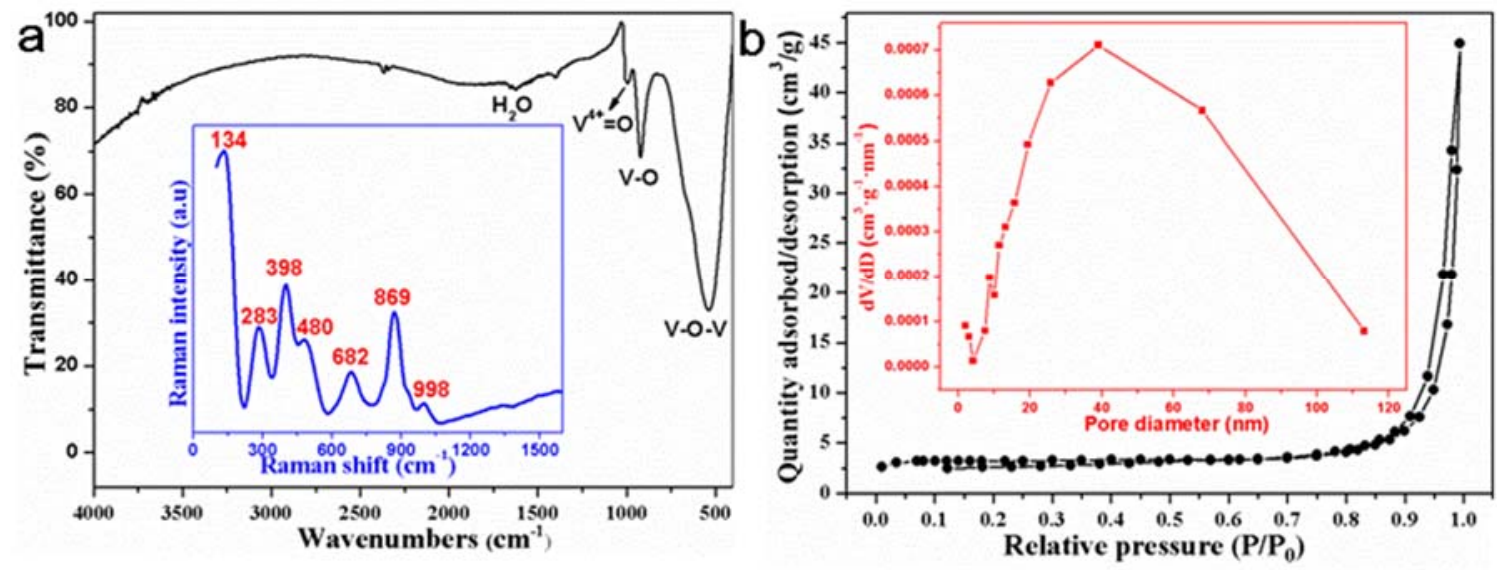

Figure 5. (a) IR and Raman spectra of $\mathrm{VO}_{2}$ (B) nanobelts; (b) $\mathrm{N}_{2}$ adsorption-desorption isotherms of the $\mathrm{VO}_{2}(\mathrm{~B})$ nanobelts at $77 \mathrm{~K}$.

Raman spectrum of the $\mathrm{VO}_{2}(\mathrm{~B})$ nanobelts is shown in Figure $5 \mathrm{a}$, which demonstrates a series of bands located at $100-1100 \mathrm{~cm}^{-1}$ are the vibrations of $\mathrm{V}-\mathrm{O}$ type of $\mathrm{VO}_{2}(\mathrm{~B})$. Specially, the intense peak at $134 \mathrm{~cm}^{-1}$ corresponds with $\mathrm{B}_{3 \mathrm{~g}}$ and $\mathrm{B}_{2 \mathrm{~g}}$ symmetry, which is indexed to the stretching vibration pattern of $\left(\mathrm{V}_{2} \mathrm{O}_{2}\right)_{\mathrm{n}}$ in agreement with the chain conversion $[29,30]$. Therefore, the results of Raman and infrared spectroscopy are consistent with those of XRD and EDS.

The nitrogen adsorption-desorption isotherms of $\mathrm{VO}_{2}(\mathrm{~B})$ nanobelts is shown in Figure $5 \mathrm{~b}$. The isotherms show that the phenomenon of capillary condensation occurs at high $\mathrm{P} / \mathrm{P}_{0}$, which is a type IV isotherm in accordance with the IUPAC classification, and $\mathrm{VO}_{2}(\mathrm{~B})$ nanobelts exhibits mesoporous material characteristics [31]. The BET surface area of $\mathrm{VO}_{2}(\mathrm{~B})$ nanobelts is $10.4 \mathrm{~m}^{2} \cdot \mathrm{g}^{-1}$ and the Barrett-Joyner-Halenda (BJH) method (insert in Figure $5 b$ ) was used to obtain the sample with a pore volume of $0.0687 \mathrm{~cm}^{3} / \mathrm{g}$ and an average pore size of $42.7 \mathrm{~nm}$. The porous characteristic of $\mathrm{VO}_{2}(\mathrm{~B})$ nanobelts indicates potential excellent electrochemical properties, which can be used as SC [32] or lithium ion battery electrodes [33] in the future.

The $\mathrm{CV}$ curves of the $\mathrm{VO}_{2}(\mathrm{~B})$ nanobelts are shown in Figure 6. The results indicate that there is a large capacity at the potential limit of $-0.8 \sim 1.0 \mathrm{~V}$ among a different potential limit. Hence, electrochemical curves of $\mathrm{VO}_{2}(\mathrm{~B})$ nanobelts were measured from $-0.8 \mathrm{~V}$ to $1.0 \mathrm{~V}$.

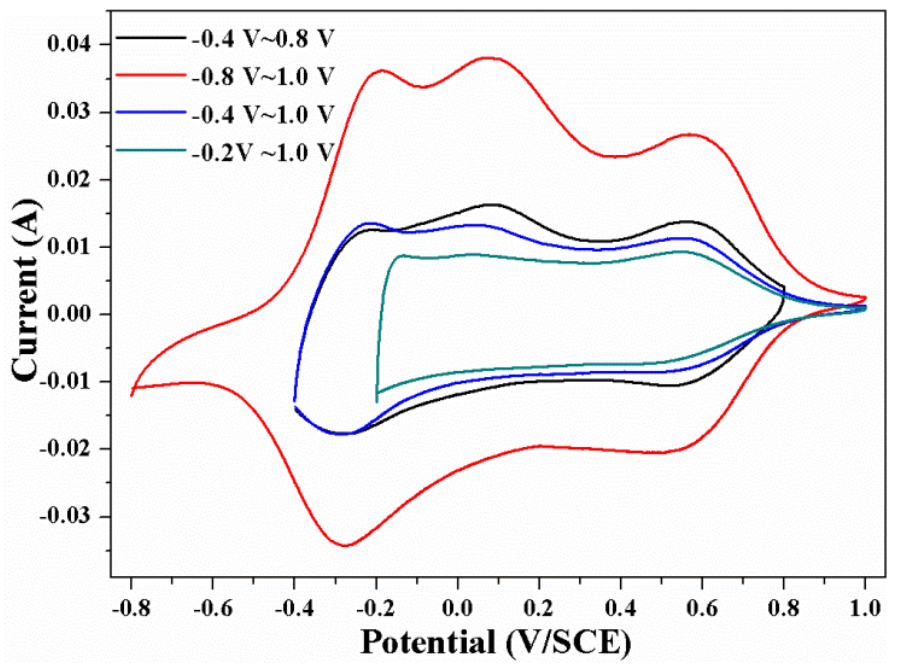

Figure 6. $\mathrm{CV}$ curves of the $\mathrm{VO}_{2}(\mathrm{~B})$ nanobelts at different potential limit $\left(20 \mathrm{mV} \cdot \mathrm{s}^{-1}, 1 \mathrm{M} \mathrm{Na} 2 \mathrm{SO}_{4}\right.$ electrolyte).

$\mathrm{CV}$ curves of the $\mathrm{VO}_{2}(\mathrm{~B})$ nanobelts at $-0.8 \sim 1.0 \mathrm{~V}$ are shown in Figure $7 \mathrm{a}$, and the scan rate is from 5 to $100 \mathrm{mV} \cdot \mathrm{s}^{-1}$. The results indicate that the redox peaks are seen, disclosing that $\mathrm{VO}_{2}(\mathrm{~B})$ nanobelts 
storing charges are mainly on basis of a redox mechanism [34]. The corresponding redox reaction is described as follows: $\mathrm{VO}_{2}+x \mathrm{Na}^{+}+x \mathrm{e}^{-} \rightarrow \mathrm{Na}_{x} \mathrm{VO}_{2}$. The $x$ denotes mole fraction of inserted $\mathrm{Na}^{+}$. Original shapes of the $\mathrm{CV}$ curves remain almost unchanged as the increment of scan rate, which indicates there are excellent ionic and electronic conductivity in the $\mathrm{VO}_{2}(\mathrm{~B})$ nanobelts. Meanwhile, the peak moves to a higher potential for the electrode polarization effect. Furthermore, the peak current enlarges as scan rate increases, which shows the faradic redox reactions at surface is rapid enough, as well as the rates of ionic and electronic transport [35]. Figure $7 \mathrm{~b}$ shows GCD curves of the $\mathrm{VO}_{2}(\mathrm{~B})$ nanobelts. When the discharge current densities are $0.5,1$ and $10 \mathrm{~A} \cdot \mathrm{g}^{-1}$, the specific capacitance are 287, 246 , and $222 \mathrm{~F} \cdot \mathrm{g}^{-1}$. As the discharge current density increases $\left(0.5-10 \mathrm{~A} \cdot \mathrm{g}^{-1}\right)$, the specific capacitance decreases. One reason is that a lower use rate of $\mathrm{VO}_{2}(\mathrm{~B})$ occurs at the high current density in the process of charge-discharge, and the other one is that the incremental voltage drop is involved in the redox reaction [36,37]. The value of capacitance at current density of $10 \mathrm{~A} \cdot \mathrm{g}^{-1}$ remains $77 \%$ of that at current density of $0.5 \mathrm{~A} \cdot \mathrm{g}^{-1}$. The good rate capability is ascribed to the belt-like (Figures 2 and 3 ) and porous (Figure $5 b$ ) structures of the $\mathrm{VO}_{2}(\mathrm{~B})$ nanobelts.
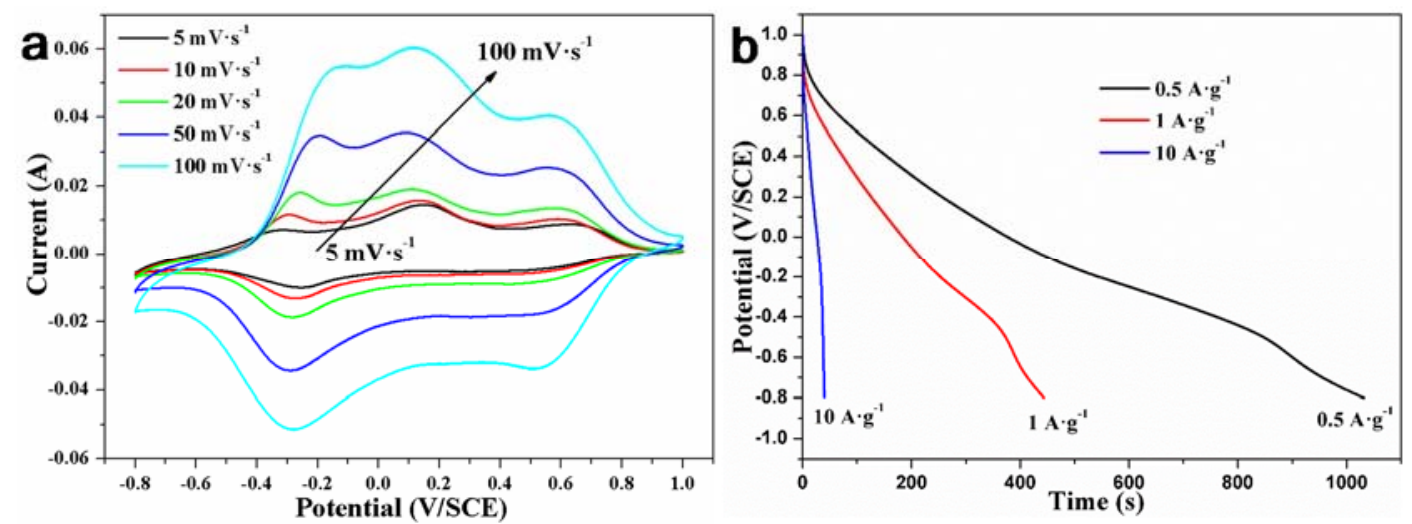

Figure 7. (a) CV curves of $\mathrm{VO}_{2}(\mathrm{~B})$ nanobelts; (b) GCD curves of $\mathrm{VO}_{2}(\mathrm{~B})$ nanobelts $\left(1 \mathrm{M} \mathrm{Na}_{2} \mathrm{SO}_{4}\right.$ electrolyte).

Table 2 displays the electrochemical properties of the $\mathrm{VO}_{2}(\mathrm{~B})$ nanobelts with other materials discovered previously. Although the stability is not as good as some materials, the specific capacitance of porous $\mathrm{VO}_{2}(\mathrm{~B})$ nanobelts $\left(287 \mathrm{~F} \cdot \mathrm{g}^{-1}\right.$ ) outperforms other materials, for example, $\mathrm{VO}_{2}(\mathrm{~B})$ particles $\left(136 \mathrm{~F}^{-1} \mathrm{~g}^{-1}\right)$ [36], $\mathrm{VO}_{2}(\mathrm{~B})$ nanofibers $\left(174 \mathrm{~F} \cdot \mathrm{g}^{-1}\right)$ [38], $\mathrm{VO}_{2}(\mathrm{~B}) / \mathrm{CNTs}\left(229 \mathrm{~F} \cdot \mathrm{g}^{-1}\right)$ [38], RG/VO $(\mathrm{B})$ hybrid composites $\left(225 \mathrm{~F} \cdot \mathrm{g}^{-1}\right)$ [36], etc. Furthermore, it is concluded from Table 2 that porous $\mathrm{VO}_{2}(\mathrm{~B})$ nanobelts can be used as a large voltage window compared to the previous reports. Therefore, porous $\mathrm{VO}_{2}(\mathrm{~B})$ nanobelts in this paper reveal large capacity as well as excellent rate capability. According to Figure $5 b$, the calculated energy density at the current density of $0.5,1$, and $10 \mathrm{~A} \cdot \mathrm{g}^{-1}$ are 129,111 , and $100 \mathrm{~W} \cdot \mathrm{h} \cdot \mathrm{kg}^{-1}$, meanwhile the power density is 450,900 , and $9000 \mathrm{~W} \cdot \mathrm{kg}^{-1}$, respectively.

Figure 8 shows the cycling stability of the porous $\mathrm{VO}_{2}(\mathrm{~B})$ nanobelts. Figure $8 \mathrm{a}$ displays the $\mathrm{CV}$ curves at various cycles, which depicts the specific capacitance fades with the cycle increasing. Figure $8 \mathrm{~b}$ shows the GCD curves to quantitatively observe the cycling stability, which displays similar results with $\mathrm{CV}$ curves. During the $\mathrm{CV}$ and GCD tests, the solution gradually turned yellow because of the dissolution of the $\mathrm{VO}_{2}(\mathrm{~B})$ nanobelts as electrode material in $\mathrm{Na}_{2} \mathrm{SO}_{4}$ electrolyte solution. This is an experimental phenomenon that often occurs when vanadium oxides are applied in SC and lithium-ion battery electrodes $[27,39,40]$. 

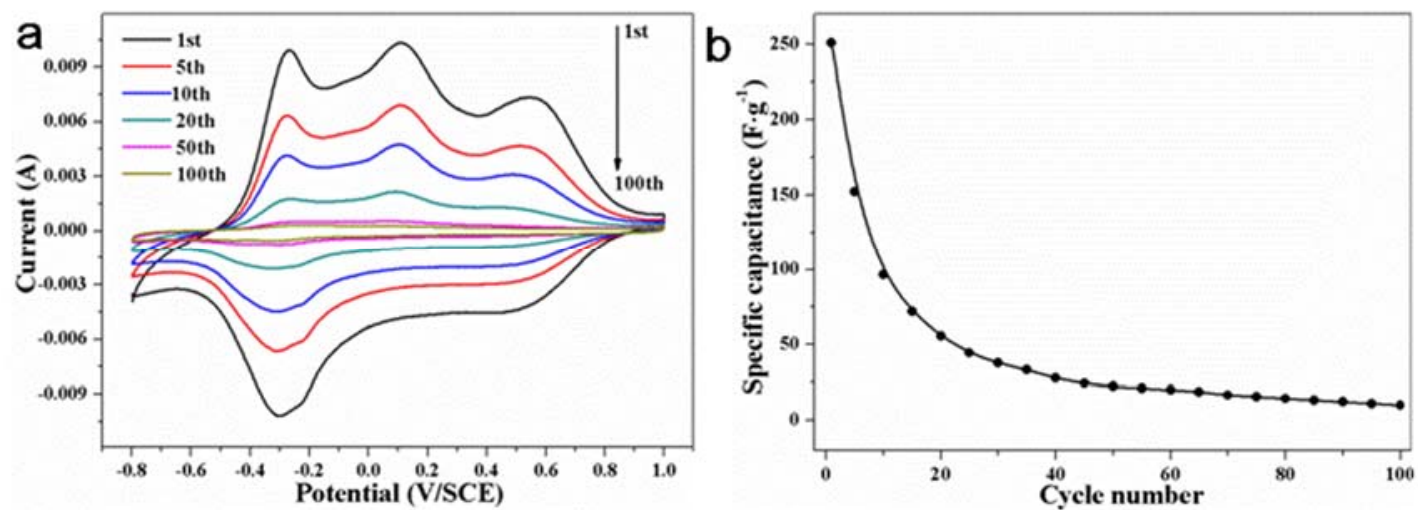

Figure 8. (a) CV cycling curves of the $\mathrm{VO}_{2}$ (B) nanobelts $\left(20 \mathrm{mV} \cdot \mathrm{s}^{-1}, 1 \mathrm{M} \mathrm{Na}_{2} \mathrm{SO}_{4}\right.$ electrolyte); (b) Cyclic stability of the specific capacitance (GCD method, $1 \mathrm{M} \mathrm{Na}_{2} \mathrm{SO}_{4}$ electrolyte).

Table 2. Comparison of the $\mathrm{VO}_{2}(\mathrm{~B})$ nanobelts with other materials discovered previously.

\begin{tabular}{|c|c|c|c|c|}
\hline Materials & Current/A.g ${ }^{-1}$ & Potential/V & Capacitance/F.g ${ }^{-1}$ & Literatures \\
\hline $\mathrm{VO}_{2}(\mathrm{~B}) / \mathrm{RG}(1.0)$ & 1 & $-0.6 \sim 0.4$ & 245 & [24] \\
\hline $\mathrm{VO}_{2}(\mathrm{~B})$ particles & 0.25 & $-0.2 \sim 0.8$ & 136 & [36] \\
\hline $\mathrm{RG}(1.0) / \mathrm{VO}_{2}(\mathrm{~B})$ & 0.25 & $-0.2 \sim 0.8$ & 225 & [36] \\
\hline $\mathrm{VO}_{2}(\mathrm{~B})$ nanofibers & 0.5 & $-0.6 \sim 0.4$ & 174 & [38] \\
\hline $\mathrm{VO}_{2}(\mathrm{~B}) / \mathrm{CNTs}$ & 0.5 & $-0.6 \sim 0.4$ & 229 & [38] \\
\hline $\mathrm{VO}_{2}(\mathrm{~B}) / \mathrm{GN}(20 \%)$ & 0.5 & $0 \sim 0.6$ & 197 & [41] \\
\hline W-doped $\mathrm{VO}_{2}(\mathrm{~B})$ nanobelts & 1 & $-0.4 \sim 0.6$ & 253 & [42] \\
\hline Porous $\mathrm{VO}_{2}(\mathrm{~B})$ nanobelts & 0.5 & $-0.8 \sim 1.0$ & 287 & This work \\
\hline Porous $\mathrm{VO}_{2}(\mathrm{~B})$ nanobelts & 1 & $-0.8 \sim 1.0$ & 246 & This work \\
\hline
\end{tabular}

\section{Conclusions}

In this study, $\mathrm{VO}_{2}(\mathrm{~B})$ nanobelts with porous structures were synthesized by using $\mathrm{NH}_{4} \mathrm{VO}_{3}$, $\mathrm{H}_{2} \mathrm{C}_{2} \mathrm{O}_{4} \cdot 2 \mathrm{H}_{2} \mathrm{O}$, and $\mathrm{H}_{2} \mathrm{O}$ through a facile hydrothermal route. The $\mathrm{VO}_{2}(\mathrm{~B})$ nanobelts were characterized by different instruments. BET surface area of the $\mathrm{VO}_{2}(\mathrm{~B})$ nanobelts is $10.4 \mathrm{~m}^{2} \cdot \mathrm{g}^{-1}$, the pore volume is $0.0687 \mathrm{~cm}^{3} / \mathrm{g}$, and the average pore size is $42.7 \mathrm{~nm}$. In terms of the electrochemical properties, the $\mathrm{VO}_{2}(\mathrm{~B})$ nanobelts exhibited that the measured capacitance was based on the pseudocapacitance with a large voltage window ranging from $-0.8 \mathrm{~V}$ to $1.0 \mathrm{~V}$. Porous $\mathrm{VO}_{2}(\mathrm{~B})$ nanobelts displayed specific capacitances of 287,246 , and $222 \mathrm{~F} \cdot \mathrm{g}^{-1}$ at the discharge current density of $0.5,1$, and $10 \mathrm{~A} \cdot \mathrm{g}^{-1}$, respectively. The $\mathrm{VO}_{2}(\mathrm{~B})$ nanobelts with a large voltage window perform good electrochemical properties, which is an ideal cathode material in the research field of SCs.

Author Contributions: Conceptualization, X.L. and C.M.; methodology, X.L.; validation, X.L., J.Z., and X.J.; formal analysis, X.J.; investigation, X.L. and Y.C.; data curation, X.L. and J.Z.; writing-original draft preparation, X.L.; writing-review and editing, X.L. and C.M.; funding acquisition, C.M. All authors have read and agreed to the published version of the manuscript.

Funding: This work is supported by the National Natural Science Foundation of China (Grant No. 21771030), Fundamental. Acknowledgments: Thanks to Yifu Zhang for his editorial assistance.

Conflicts of Interest: The authors declare no conflicts of interest.

\section{References}

1. Bi, W.C.; Wang, J.C.; Jahrman, E.P.; Seidler, G.T.; Gao, G.H.; Wu, G.M.; Cao, G.Z. Interface Engineering $\mathrm{V}_{2} \mathrm{O}_{5}$ Nanofibers for High-Energy and Durable Supercapacitors. Small. 2019, 15, 1901747. [CrossRef] [PubMed]

2. Song, Z.Y.; Duan, H.; Li, L.C. High-energy flexible solid-state supercapacitors based on O, N, S-tridoped carbon electrodes and a $3.5 \mathrm{~V}$ gel-type electrolyte. Chem. Eng. J. 2019, 372, 1216-1225. [CrossRef] 
3. Qiu, N.; Chen, H.; Yang, Z.M.; Sun, S.; Wang, Y. Low-cost birnessite as a promising cathode for high-performance aqueous rechargeable batteries. Electrochim. Acta 2018, 272, 154-160. [CrossRef]

4. Lin, Z.H.; Xiong, X.H.; Fan, M.N.; Xie, D.; Wang, G.; Yang, C.H.; Liu, M.L. Scalable synthesis of FeS 2 nanoparticles encapsulated into $\mathrm{N}$-doped carbon nanosheets as a high-performance sodium-ion battery anode. Nanoscale 2018, 10, 22329-22334. [CrossRef] [PubMed]

5. Xu, X.M.; Xiong, F.Y.; Meng, J.S.; Wang, X.P.; Niu, C.J.; An, Q.Y.; Mai, L.P. Vanadium-Based Nanomaterials: A Promising Family for Emerging Metal-Ion Batteries. Adv. Funct. Mater. 2020, 30, 1904398. [CrossRef]

6. Wang, X.D.; Song, J.H.; Liu, J.; Wang, Z.L. Direct-current nanogenerator driven by ultrasonic waves. Science 2007, 316, 102-105. [CrossRef]

7. Liang, X.; Zhao, L.; Wang, Q.F.; Ma, Y.; Zhang, D.H. A dynamic stretchable and self-healable supercapacitor with a CNT/graphene/PANI composite film. Nanoscale 2019, 11, 3773-3779. [CrossRef]

8. Zhao, Y.J.; Ding, C.H.; Hao, Y.N.; Zhai, X.M.; Wang, C.Z.; Li, Y.T.; Li, J.B.; Jin, H.B. Neat Design for the Structure of Electrode To Optimize the Lithium-Ion Battery Performance. ACS Appl. Mater. Interfaces 2018, 10, 27106-27115. [CrossRef]

9. Balogun, M.S.; Yang, H.; Luo, Y.; Qiu, W.T.; Huang, Y.C.; Liu, Z.Q.; Tong, Y.X. Achieving high gravimetric energy density for flexible lithium-ion batteries facilitated by core-double-shell electrodes. Energy Environ. Sci. 2018, 11, 1859-1869. [CrossRef]

10. Han, Y.; Lu, Y.Z.; Shen, S.H.; Zhong, Y.; Liu, S.; Xia, X.H.; Tong, Y.X.; Lu, X.H. Enhancing the Capacitive Storage Performance of Carbon Fiber Textile by Surface and Structural Modulation for Advanced Flexible Asymmetric Supercapacitors. Adv. Funct. Mater. 2019, 29, 1806329. [CrossRef]

11. Zhang, Y.; Liu, J.; Li, S.L.; Su, Z.M.; Lan, Y.Q. Polyoxometalate-based materials for sustainable and clean energy conversion and storage. Energy Chem. 2019, 1, 100021. [CrossRef]

12. Althumairy, D.; Murakami, H.A.; Zhang, D.M.; Barisas, B.G.; Roess, D.A.; Crans, D.C. Effects of vanadium(IV) compounds on plasma membrane lipids lead to $\mathrm{G}$ protein-coupled receptor signal transduction. J. Inorg. Biochem. 2020, 203, 110873. [CrossRef] [PubMed]

13. Bolokang, A.S.; Motaung, D.E. Reduction-oxidation of $\mathrm{V}_{2} \mathrm{O}_{5}-\mathrm{WO}_{3}$ nanostructured by ball milling and annealing: Their improved $\mathrm{H}_{2} \mathrm{~S}$ gas sensing performance. Appl. Surf. Sci. 2019, 43, 164-173. [CrossRef]

14. Liu, K.; Lee, S.; Delaire, O.; Wu, J.Q.; Yang, S. Recent progresses on physics and applications of vanadium dioxide. Mater. Today. 2018, 21, 875-896. [CrossRef]

15. Lu, N.P.; Zhang, P.F.; Zhang, Q.H.; Qiao, R.M.; Wu, J.; Tokura, Y.; Yu, P. Electric-field control of tri-state phase transformation with a selective dual-ion switch. Nature 2017, 546, 124-128. [CrossRef] [PubMed]

16. Théobald, F.; Cabala, R.; Bernard, J. Essai sur la structure de $\mathrm{VO}_{2}$ (B). J. Solid State Chem. 1976, 17, 431-438. [CrossRef]

17. Georg, A. Studies on Vanadium Oxides. II. The Crystal Structure of Vanadium Dioxide. Acta Chem. Scand. 1956, 10, 623-628.

18. Sven, W. Note on a Phase Transition in $\mathrm{VO}_{2}$. Acta Chem. Scand. 1961, 15, 217.

19. Oka, Y.; Sato, S.; Yao, T.; Yamamoto, N. Crystal Structures and Transition Mechanism of $\mathrm{VO}_{2}(\mathrm{~A})$. J. Solid State Chem. 1998, 141, 594-598. [CrossRef]

20. Li, R.X.; Yu, X.; Bian, X.F.; Hu, F. Preparation and electrochemical performance of $\mathrm{VO}_{2}(\mathrm{~A})$ hollow spheres as a cathode for aqueous zinc ion batteries. RSC Adv. 2019, 9, 35117-35123. [CrossRef]

21. Zhang, Y.F.; Zhang, H.Z.; Huang, Y.; Huang, C.; Niu, F.; Meng, C.G.; Tan, X.Y. One-step hydrothermal conversion of $\mathrm{VO}_{2}(\mathrm{~B})$ into $\mathrm{W}$-doped $\mathrm{VO}_{2}(\mathrm{M})$ and its phase transition and optical switching properties. Solid State Comm. 2014, 180, 24-27. [CrossRef]

22. Li, L.Y.; Liu, P.C.; Zhu, K.J.; Wang, J.; Liu, J.S.; Qiu, J.H. A general and simple method to synthesize well-crystallized nanostructured vanadium oxides for high performance Li-ion batteries. J. Mater. Chem. A 2015, 3, 9385-9389. [CrossRef]

23. Zhang, L.; Zhao, K.M.; Xu, W.W.; Meng, J.S.; He, L.; An, Q.Y.; Xu, X.; Luo, Y.Z.; Zhao, T.W.; Mai, L.Q. Mesoporous $\mathrm{VO}_{2}$ nanowires with excellent cycling stability and enhanced rate capability for lithium batteries. RSC Adv. 2014, 4, 33332-33337. [CrossRef]

24. Xiao, X.X.; Li, S.; Wei, H.; Sun, D.; Wu, Y.Z.; Jin, G.Z.; Wang, F.; Zou, Y.P. Synthesis and characterization of $\mathrm{VO}_{2}(\mathrm{~B}) /$ graphene nanocomposite for supercapacitors. J. Mater. Sci.: Mater. Electron. 2015, 26, 4226-4233. [CrossRef] 
25. Gu, L.P.; Wang, J.; Ding, J.W.; Li, B.; Yang, S.B. W-doped $\mathrm{VO}_{2}$ (B) nanosheets-built 3D networks for fast lithium storage at high temperatures. Electrochim. Acta 2019, 295, 393-400. [CrossRef]

26. Cui, F.H.; Zhao, J.; Zhang, D.X.; Fang, Y.Z.; Zhu, K. $\mathrm{VO}_{2}(\mathrm{~B})$ nanobelts and reduced graphene oxides composites as cathode materials for low-cost rechargeable aqueous zinc ion batteries. Chem. Eng. J. 2020, 390, 124118. [CrossRef]

27. Kong, D.B.; Li, X.G.; Zhang, W.B.; Hai, X.; Wang, B.; Qiu, X.Y.; Song, Q.; Yang, Q.H.; Zhi, L.J. Encapsulating $\mathrm{V}_{2} \mathrm{O}_{5}$ into carbon nanotubes enables the synthesis of flexible high-performance lithium ion batteries. Energy Environ. Sci. 2016, 9, 906-911. [CrossRef]

28. Gilson, T.R.; Bizri, O.F.; Cheetham, N. Single-crystal Raman and infrared spectra of vanadium (V) oxide. J. Chem. Soc. Dalton Trans. 1973, 291-294. [CrossRef]

29. Faggio, G.; Modafferi, V.; Panzera, G.; Alfieri, D.; Santangelo, S. Micro-Raman and photoluminescence analysis of composite vanadium oxide/poly-vinyl acetate fibres synthesised by electro-spinning. J. Raman Spectrosc. 2012, 43, 761-768. [CrossRef]

30. Baddour-Hadjean, R.; Marzouk, A.; Pereira-Ramos, J.P. Structural modifications of LixV2O5 in a composite cathode $(0 \leq x<2)$ investigated by Raman microspectrometry. J. Raman Spectrosc. 2012, 43, 153-160.

31. Sing, K.; Everett, D.H.; Haul, R.; Moscou, L.; Pierotti, R.; Rouquerol, J.; Siemieniewska, T. Reporting physisorption data for gas/solid systems with special reference to the determination of surface area and porosity. Pure Appl. Chem. 1985, 57, 603-619. [CrossRef]

32. Baudrin, E.; Sudant, G.; Larcher, D.; Dunn, B.; Tarascon, J.M. Preparation of Nanotextured $\mathrm{VO}_{2}[\mathrm{~B}]$ from Vanadium Oxide Aerogels. Chem. Mater. 2006, 18, 4369-4374. [CrossRef]

33. Zhang, C.F.; Chen, Z.X.; Guo, Z.P.; Lou, X.W. Additive-free synthesis of $3 \mathrm{D}$ porous $\mathrm{V}_{2} \mathrm{O}_{5}$ hierarchical microspheres with enhanced lithium storage properties. Energy Environ. Sci. 2013, 6, 974-978. [CrossRef]

34. Augustyn, V.; Come, J.; Lowe, M.A.; Kim, J.W.; Taberna, P.L.; Tolbert, S.H.; Abruña, P.S.; Dunn, B. High-rate electrochemical energy storage through $\mathrm{Li}^{+}$intercalation pseudocapacitance. Nat. Mater. 2013, 12, 518-522. [CrossRef]

35. Wang, H.W.; Yi, H.; Chen, X.; Wang, X.F. One-step strategy to three-dimensional graphene/ $\mathrm{VO}_{2}$ nanobelt composite hydrogels for high performance supercapacitors. J. Mater. Chem. A 2014, 2, 1165-1173. [CrossRef]

36. Deng, L.J.; Zhang, G.N.; Kang, L.P.; Lei, Z.B.; Liu, C.L.; Liu, Z.H. Graphene/ $/ \mathrm{VO}_{2}$ hybrid material for high performance electrochemical capacitor. Electrochim. Acta 2013, 112, 448-457. [CrossRef]

37. Yu, Z.N.; Tetard, L.; Zhai, L.; Thomas, J. Supercapacitor electrode materials: Nanostructures from 0 to 3 dimensions. Energy Environ. Sci. 2015, 8, 702-730. [CrossRef]

38. Liang, L.Y.; Liu, H.M.; Yang, W.S. Fabrication of $\mathrm{VO}_{2}(\mathrm{~B})$ hybrid with multiwalled carbon nanotubes to form a coaxial structure and its electrochemical capacitance performance. J. Alloy. Compd. 2013, 559, 167-173. [CrossRef]

39. Li, H.Y.; Wei, C.; Wang, L.; Zuo, Q.S.; Li, X.L.; Xie, B. Hierarchical vanadium oxide microspheres forming from hyperbranched nanoribbons as remarkably high performance electrode materials for supercapacitors. J. Mater. Chem. A 2015, 3, 22892-22901. [CrossRef]

40. Zhang, Y.F.; Zheng, J.Q.; Hu, T.; Tian, F.P.; Meng, C.G. Synthesis and supercapacitor electrode of $\mathrm{VO}_{2}(\mathrm{~B}) /$ Core-shell composites with a pseudocapacitance in aqueous solution. Appl. Surf. Sci. 2016, 371, 189-195. [CrossRef]

41. Zhang, J.Y.; Chen, L.Z.; Wang, Y.X.; Cai, S.Y.; Yang, H.J.; Yu, H.; Ding, F.Y.; Huang, C.; Liu, X.H. $\mathrm{VO}_{2}(\mathrm{~B}) /$ Graphene Composite-Based Symmetrical Supercapacitor Electrode via Screen Printing for Intelligent Packaging. Nanomaterials 2018, 8, 1020. [CrossRef] [PubMed]

42. Zhang, Y.F.; Huang, Y.T. A facile hydrothermal synthesis of tungsten doped monoclinic vanadium dioxide with B phase for supercapacitor electrode with pseudocapacitance. Mater. Lett. 2016, 182, 285-288. [CrossRef]

(C) 2020 by the authors. Licensee MDPI, Basel, Switzerland. This article is an open access article distributed under the terms and conditions of the Creative Commons Attribution (CC BY) license (http://creativecommons.org/licenses/by/4.0/). 